\title{
Demographic and socioeconomic profiles of patients admitted with diabetic foot complications in a tertiary hospital in Belem - Para
}

\section{Perfil socioeconômico e demográfico de pacientes internados por complicações nos pés diabéticos em um hospital terciário em Belém - Pará}

José Maciel Caldas dos Reis ${ }^{1}$ iD; Robson Roberto Melo Wanzeller, AsCbC-PA²; Wilame Melo Meireles, AsCbC-PA²; Mariseth Carvalho de Andrade33; Victor Hugo Guerreiro Américo Gomes; josé Aroldo Alves Arrais²; Geraldo Ishak, TCBC-PA².

\section{A B S T R A C T}

\begin{abstract}
Objective: to assess the socioeconomic and demographic profiles of patients hospitalized with a diagnosis of diabetic foot in a tertiary hospital in Belem-PA, Brazil, as well as to evaluate risk factors for lower limb amputations in such patients, classifying them according to the Wagner and PEDIS classifications. Methods: we conducted a descriptive, cross-sectional, unicentric, and analytical study carried out through a structured questionnaire. Results: the study consisted of 57 patients, aged between 48 and 84 years old, $66.7 \%$ being male. The average income ranged between one and three (61.4\%) minimum wages and below one minimum wage (31.6\%). Type II Diabetes Mellitus was predominant (86.0\%). Concerning comorbidities, arterial hypertension displayed the highest proportion (62.3\%), followed by dyslipidemia (52.8\%). Smokers comprised $35.1 \%$ of the sample. Infectious diabetic foot (50.9\%) and mixed diabetic foot (49.1\%) were the most common. Of the 20 patients with previous amputation, $90 \%$ had undergone minor amputation, and 10\%, major ones. Callosity (92.6\%) was the most prevalent deformity. Fifty-four (94.7\%) patients underwent surgery, those being debridement (24.1\%), minor amputation (37.0\%) and major amputation (38.9\%). During hospitalization, $78.9 \%$ of individuals did not require ICU stay. Hospitalization time varied between three and 59 days, and $78.9 \%$ of hospitalized patients did not progress to death, but $43.1 \%$ of patients submitted to major amputations died. Conclusion: patients with diabetic foot followed-up have a low socioeconomic profile; most of them underwent surgical procedures, whether major or minor, due to the higher prevalence of infectious diabetic foot and/or non-adherence to non-operative treatment.
\end{abstract}

Keywords: Diabetic Foot. Amputation. Lower Extremity. Risk Factors.

\section{INTRODUCTION}

Diabetes mellitus (DM) is a chronic metabolic disease with persistent hyperglycemia, caused by hereditary and environmental factors, resulting from defects in the secretion or action of insulin, or both ${ }^{1,2,3}$. The disease can be classified into type 1 DM, with autoimmune origin, resulting from the destruction of pancreatic $\beta$-cells that causes complete insulin deficiency, and type 2 DM, characterized by insulin resistance ${ }^{2,3}$.

According to the International Diabetes Federation, $8.8 \%$ of the world population aged $20-79$ years (415 million people) lived with diabetes in $2015^{2}$. It is estimated that there will be 642 million diabetics in $2040^{2}$.
In Brazil, there are about 13 million diabetics, and the country occupies the $4^{\text {th }}$ position in the world ranking. Between 2006 and 2017, there was an increase in cases of $54 \%$ among men and $28 \%$ among women, with emphasis on people over 65 years of age and low education ${ }^{2,3}$

The main aggravating factor for patients with DM is the high rate of complications that affect quality of life, generating economic, social, and psychological consequences. For this reason, it represents a major public health problem ${ }^{4-6}$.

The main diabetes complications are due to micro and macrovascular changes, which result in retinopathy, nephropathy, neuropathy, and coronary, cerebrovascular, and peripheral arterial diseases ${ }^{2}$.

1 - Centro Universitário Metropolitano da Amazônia (UNIFAMAZ), Cirurgia Vascular, Disciplina de Habilidades Cirúrgicas - Belém - PA - Brasil 2 - Hospital Universitário João de Barros Barreto, Departamento de Cirurgia Geral e do Aparelho Digestivo - Belém - PA - Brasil 3 Universidade do Estado do Pará (UEPA), Disciplina de Estatística - Belém - Pará - Brasil 4 Universidade Federal do Pará (UFPA), Cirurgia Vascular - Belém - PA - Brasil 
The diabetic foot, responsible for $20 \%$ to $25 \%$ of the hospitalizations of such patients, can be defined as infection, ulceration and/or destruction of deep tissues, associated with peripheral neurological and vascular changes in the lower limb $b^{2,3,7}$. It has a significant impact on morbidity and mortality, as five out of six major limb amputations are performed in diabetic patients and $85 \%$ of amputations in this population are preceded by ulceration ${ }^{4,5}$. These individuals are 15 to 40 times more likely to suffer amputations than non-diabetics, with a $20 \%$ mortality rate in two years. This generates a great burden on the social security system, with early retirements and high hospital costs for treatment and rehabilitation ${ }^{4,5}$.

Studies point to important factors that influence the diagnosis of diabetic foot, such as advanced age, type and time of diagnosis of DM, inadequate metabolic control, smoking, alcoholism, obesity, high blood pressure, and lack of good hygienic habits in foot care. Thus, a multifactorial and interdisciplinary approach is important to try to prevent or minimize its occurrence ${ }^{1,2,4,7-9}$.

Sensitized by these data, and due to the high prevalence in our region, this research aims to assess the socioeconomic and demographic profiles of patients admitted with a diagnosis of diabetic foot in a tertiary hospital in Belem, state of Para, Brazil.

\section{METHODS}

The present study is a cross-sectional, descriptive research carried out using a structured questionnaire with objective questions. The study was conducted from June to December 2019, at the João de Barros Barreto University Hospital (HUJBB).

We collected data through interviews with patients or guardians, and filled the questionnaires after the signature of an Informed Consent Form (ICF). The study was approved by the Ethics in Research Committee of the HUJBB, under protocol CAAE: 28313419.6.0000.0017. All information was kept confidential, without identifying the patients, under the responsibility of the researcher.

The protocol was composed of objective questions regarding the epidemiological profile, as to sex, age, marital status, occupation, life habits, and family history, and the clinical profile, with emphasis on risk factors for diabetic foot, comorbidities, type of DM, time of diagnosis, frequency of outpatient visits, use of insulin and oral antidiabetics, DM complications, presence of infection, cause of injury, time of ulceration, and the Wagner and PEDIS classifications.

We included patients diagnosed with diabetic foot admitted to the HUJBB and attended by the vascular surgeon, and who agreed to participate in the research.

We stored the collected information in a database prepared in Microsoft $₫$ Office Excel $® 2016$ software.

In the application of Descriptive Statistics, we constructed tables and graphs to present the results and calculated the position statistics, such as the arithmetic mean and the standard deviation.

We used analytical statistics to evaluate the results of the sample's categorical variables using the $G$ and Chi-Square Adherence Tests for univariate tables and the $G$ and Chi-Square Independence Tests for bivariate tables.

We performed descriptive and analytical statistics with the BioEstat @ 5.4 software. For decisionmaking, we adopted the significance level $\alpha=0.05$, or $5 \%$, signaling the significant values with an asterisk (*).

\section{RESULTS}

The study sample consisted of 57 patients, with a mean age of 63.2 years, a statistically significant proportion of male patients, married, retired, and coming from the metropolitan region. Table 1 shows additional data, including regarding income and housing.

Type II Diabetes Mellitus was predominant among the patients in the sample $(86.0 \%)$. This proportion was statistically significant $(p<0.0001)$ in relation to type I (14.0\%). On average, patients had been diagnosed 11.1 years before, this time ranging from one to 35 years.

The use of oral hypoglycemic drugs predominated $(56.1 \%)$ over the other modalities, as recorded in Table 2.

Table 3 illustrates the distribution of patients according to the presence of comorbidities. 
Table 1. Sociodemographic profile of patients with diabetic foot, HUJBB, Jun-Dec/2019.

\begin{tabular}{|c|c|c|c|}
\hline Sociodemographic profile & Frequency & $\%(\mathrm{~N}=57)$ & p-value \\
\hline Sex & & & $0.0171 *$ \\
\hline Female & 19 & $33.3 \%$ & \\
\hline Male* & 38 & $66.7 \%$ & \\
\hline Age & & & $0.0002 * *$ \\
\hline$<50$ & 3 & $5.3 \%$ & \\
\hline 50 to $59 *$ & 19 & $33.3 \%$ & \\
\hline 60 to $69 *$ & 20 & $35.1 \%$ & \\
\hline 70 to 79 & 10 & $17.5 \%$ & \\
\hline$\geq 80$ & 5 & $8.8 \%$ & \\
\hline Min / Mean \pm SD / Max & $48 / 6$ & & \\
\hline Origin & & & 0.0003 * \\
\hline Metropolitan region* & 42 & $73.7 \%$ & \\
\hline Countryside & 15 & $26.3 \%$ & \\
\hline Marital status & & & $0.0029 * *$ \\
\hline Married* & 30 & $52.6 \%$ & \\
\hline Single & 18 & $31.6 \%$ & \\
\hline Widow(er) & 7 & $12.3 \%$ & \\
\hline Divorced & 2 & $3.5 \%$ & \\
\hline Occupation & & & 0.0498 * \\
\hline Retired* & 27 & $47.4 \%$ & \\
\hline Employed & 18 & $31.6 \%$ & \\
\hline Unemployed & 12 & $21.0 \%$ & \\
\hline Income (MW) & & & $<0.0001 * *$ \\
\hline$<1$ & 18 & $31.6 \%$ & \\
\hline 1 to $3^{*}$ & 35 & $61.4 \%$ & \\
\hline$>3$ & 4 & $7.0 \%$ & \\
\hline Housing situation & & & $<0.0001 *$ \\
\hline Lives with family * & 48 & $84.2 \%$ & \\
\hline Lives alone & 9 & $15.8 \%$ & \\
\hline
\end{tabular}

Source: General Surgery Service. ${ }^{*}$ Chi-square test and ** G Adherence test; SD: Standard Deviation; MW: Minimum wage.

Table 2. Diagnostic data for patients with diabetic foot, HUJBB, Jun-Dec./2019.

\begin{tabular}{|c|c|c|c|c|}
\hline & Diagnostic Data & Frequency & $\%(N=57)$ & $p$-value \\
\hline \multirow[t]{3}{*}{ DM type } & & & & $<0.0001 *$ \\
\hline & DM Type I & 8 & $14.0 \%$ & \\
\hline & DM Type $\|$ * & 49 & $86.0 \%$ & \\
\hline \multirow[t]{8}{*}{ Diagnostic time (years) } & & & & $<0.0001 * *$ \\
\hline & 1 to 3 & 3 & $5.3 \%$ & \\
\hline & 4 to 6 & 6 & $10.5 \%$ & \\
\hline & 7 to $9 * *$ & 17 & $29.8 \%$ & \\
\hline & 10 to 12 & 14 & $24.6 \%$ & \\
\hline & 13 to 15 & 9 & $15.8 \%$ & \\
\hline & $>15$ & 8 & $14.0 \%$ & \\
\hline & Min / Mean \pm SD / Max & $01 /$ & & \\
\hline \multirow[t]{4}{*}{ Type of treatment } & & & & $0.0011 *$ \\
\hline & Hypoglycemic* & 32 & $56.1 \%$ & \\
\hline & Insulin & 14 & $24.6 \%$ & \\
\hline & Combined & 11 & $19.3 \%$ & \\
\hline
\end{tabular}


Table 3. Evaluation of comorbidities, HUJBB, Jun-Dec/2019.

\begin{tabular}{|c|c|c|c|}
\hline Evaluation of comorbidities & Frequency & $\%(N=57)$ & p-value \\
\hline Comorbidities & & & $<0.0001 * *$ \\
\hline Present** & 53 & $93.0 \%$ & \\
\hline Absence & 4 & $7.0 \%$ & \\
\hline What comorbidities & & $n=53$ & \\
\hline SAH * & 33 & $62.3 \%$ & 0.0214 * \\
\hline Dyslipidemia & 28 & $52.8 \%$ & \\
\hline Stroke & 13 & $24.5 \%$ & \\
\hline CRF & 12 & $22.6 \%$ & \\
\hline AMI & 7 & $13.2 \%$ & \\
\hline
\end{tabular}

Source: General Surgery Service *. Chi-square test and ** Adherence G test; SAH: Systemic Arterial Hypertension; CRF: Chronic Renal Failure; AMI: Acute Myocardial Infarction.

There was a statistically significant proportion ( $p=0.0243$ ) of non-alcoholic patients $(64.9 \%)$, while there was no significant difference $(p=0.1040)$ between smokers (35.1\%), nonsmokers (43.9\%) and ex-smokers (21.1\%).

Most patients had neuropathy (59.6\%), with statistical significance $(p=0.0050)$. The predominant types of diabetic foot were infectious (50.9\%) and mixed $(49.1 \%, p=0.8946)$.

We observed that approximately a third of the cases (35.1\%) had previously undergone amputation. Of these 20 patients with a history of previous amputation, minor amputation occurred in $18(90.0 \%)$, and major amputation in two (10.0\%), ( $p$ $<0.0001)$.

As for the biomechanical changes in the foot, there was no statistically significant difference $(p=$ $0.7911)$ between the proportions of present $(47.4 \%)$ and absent (52.6\%) deformities. Table 4 shows this distribution.

Table 4. Patients' distribution according to biomechanical changes in the foot, HUJBB, Jun-Dec/2019.

\begin{tabular}{|c|c|c|c|}
\hline Biomechanical changes in the foot & Frequency & $\%(N=57)$ & $p$-value \\
\hline Presence of deformities & & & 0.7911 \\
\hline Yes & 27 & $47.4 \%$ & \\
\hline Deformities & 30 & $\begin{array}{l}52.6 \% \\
N=27\end{array}$ & \\
\hline Callosity * & 25 & $92.6 \%$ & $<0.0001$ * \\
\hline Metatarsal prominences & 14 & $51.9 \%$ & \\
\hline Claw finger & 13 & $48.1 \%$ & \\
\hline Finger overlap & 7 & $25.9 \%$ & \\
\hline
\end{tabular}

Source: General Surgery Service. ${ }^{*}$ Chi-square test.

A statistically significant number of patients (54 - 94.7\%) underwent surgery during hospitalization. The surgeries performed were debridement $(24.1 \%)$, minor amputation (37.0\%), and major amputation (38.9\%).

The majority of amputations classified as minor were of the foot $(60.0 \%)$, followed by toes $(40.0 \%)$. Among those classified as major amputations, the majority were of the leg $(61.9 \%)$, followed by the thigh (38.1\%), as recorded in Table 5.

A statistically significant proportion $(p<0.0001)$ of patients did not require ICU admission (78.9\%).

Hospitalization time varied between three and 59 days, with an average of approximately 20 days, with no statistically significant difference $(p=0.4138)$ between 
the grouping ranges.

Twelve patients died during hospitalization $(21.1 \%)$ with a statistically significant predominance in cases undergoing major amputation $(38.1 \%, p=0.0252)$.

Table 6 shows the distribution of cases according to the Wagner and PEDIS classifications (Perfusion, Extent, Depth, Infection and Sensation). Only one patient displayed a grade 0 Wagner classification, and none, a grade I PEDIS classification. We found a statistically significant difference in the Wagner Grade 4 and PEDIS grade III.

Table 5. Analysis of employed treatment, HUJBB, Jun-Dec/2019.

\begin{tabular}{|c|c|c|c|}
\hline Treatment employed & Frequency & $\%(N=57)$ & $p$-value \\
\hline Surgery & & & $<0.0001 * *$ \\
\hline Yes* & 54 & $94.7 \%$ & \\
\hline No & 3 & $5.3 \%$ & \\
\hline Surgery performed & & $n=54$ & 0.3480 \\
\hline Debridement & 13 & $24.1 \%$ & \\
\hline Minor amputation & 20 & $37.0 \%$ & \\
\hline Major amputation & 21 & $38.9 \%$ & \\
\hline Minor amputation & & $n=20$ & 0.3711 \\
\hline Toe & 8 & $40.0 \%$ & \\
\hline Foot & 12 & $60.0 \%$ & \\
\hline Major amputation & & $n=21$ & 0.2752 \\
\hline Leg & 13 & $61.9 \%$ & \\
\hline Thigh & 8 & $38.1 \%$ & \\
\hline
\end{tabular}

Source: General Surgery Service. *Chi-square test and ${ }^{*}$ * G Adherence test.

Table 6. Severity according to the Wagner and PEDIS classifications, HUJBB, Jun-Dec/2019.

\begin{tabular}{lccc}
\hline \multicolumn{1}{c}{ Classification of Diabetic Foot } & Frequency & $\%(\mathrm{~N}=57)$ & $\mathrm{p}$-value \\
\hline Wagner scale & & & $<0.0001 * *$ \\
Grade 0: High risk, absence of ulcer & 1 & $1.8 \%$ & \\
Grade 2: Deep ulcer with infection & 11 & $19.3 \%$ & \\
Grade 3: Deep ulcer with osteomyelitis & 20 & $45.1 \%$ & \\
Grade 4: Gangrene localized topedis part of & 25 & & \\
the foot * & & & $0.0244 *$ \\
PEDIS Scale & 12 & $21.1 \%$ & \\
Grade II: Mild & 28 & $49.1 \%$ & \\
Grade III: Moderate * & 16 & $28.1 \%$ & \\
Grade IV: Severe &
\end{tabular}

Source: General Surgery Service. ${ }^{*}$ Chi-square test and ${ }^{* *} \mathrm{G}$ Adherence test.

\section{DISCUSSION}

Diabetes has reached epidemic proportions worldwide ${ }^{2}$. There were 451 million estimated people with diabetes in 2017, and that number will increase to 693 million people by $2045^{7,8}$.

The prevalence of Diabetes mellitus is more common in women. However, the risk of developing diabetic foot and its complications is higher in men. In the present study, we observed a higher proportion of male patients with diabetic foot $(66.7 \%)$, which is in line with most national and international studies. These suggest that women have a longer life expectancy than men, are more concerned with health, and thus seek primary health care services, aiming at preventive measures, unlike the male population. Thus, the risk of amputation due to diabetes is twice as high among men who delay searching for treatment, increasing the risk of complications ${ }^{2,7,10}$.

The mean age of patients was 63.2 years, close to that found in other national studies ${ }^{5-7,11,12}$. The high average age, especially in amputee patients, 
can compromise the rehabilitation process, since they naturally develop changes in gait and balance due to senility ${ }^{7}$.

Most patients came from the metropolitan region $(73.7 \%)$, in contrast to other studies such as the one from Nunes et al., in 2006, carried out in the state of Sergipe, in which $71 \%$ of those hospitalized for diabetic foot were from the countryside ${ }^{12}$.

Most patients had an estimated income between one and three minimum wages (61.4\%) and most had low education (incomplete elementary school), a profile similar to that found by Pitta et al. in $2005^{7}$. This often reflects the difficulty of understanding and the need for self-care of the feet, as measures to prevent ulcerations and consequently the risk of amputation. According to the International Consensus on Diabetic Foot, adequate footwear can prevent ulcers from recurring by up to $85 \%{ }^{10}$.

A 2017 systematic review found a prevalence of foot ulcers among diabetic patients varying from 3\% to $13 \%$ worldwide 4 . It represents an important cause of hospitalization among these individuals, reaching up to $25 \%$ and having a great impact on the potential loss of the limb, which can reach proportions of up to $20 \%{ }^{4}$. Poor glycemic control plays a major role in the installation and development of chronic complications, which increase the risk of neuropathy, and consequently, injury or ulceration in the feet ${ }^{4,5,7}$.

In the present study, we found type II Diabetes Mellitus in $86.0 \%$ of cases and, on average, patients had been diagnosed for 11.1 years, similar to the studies conducted by Borboletto et al. and Pitta et al.6,7.

Most patients had at least one comorbidity (93.0\%). Systemic Arterial Hypertension was the main one $(62.3 \%)$ and, based on the current literature, it is related to the development and progression of chronic complications of diabetes mellitus ${ }^{7}$.

Neuropathy was present in most patients (59.6\%), followed by retinopathy and nephropathy. Nonetheless, the most prevalent type of diabetic foot was infectious (50.9\%), which may explain the need for intervention in a significant portion of patients admitted to the institution $7,10,11$.

Diabetic patients are $19 \%$ to $34 \%$ likely to develop foot ulceration during their lifetime ${ }^{12-13}$. We observed $47.4 \%$ of patients with some deformity. The most common alteration was callus, with $43.8 \%$ of the total number of patients. Andrade et al. found callosity in $2 / 3$ of the patients, this deformity being closely related to neuropathy ${ }^{14}$.

Diabetic patients are at a 30 times greater risk of lifelong amputations, and the International Diabetes Federation estimates that at least one limb is lost due to diabetic foot somewhere in the world every 30 seconds. Patients who underwent surgical treatment during hospitalization represented $94.7 \%$ of the sample. Also, $75.9 \%$ of patients progress to some type of amputation, with $37 \%$ minor amputation, and 38.9\%, major ${ }^{12,15}$. Even though no significant differences were observed in the various studies on the global incidence of amputations in diabetics, this is a high number comparing with those reported by international studies, which show rates between $11 \%$ and $29 \%^{12}$.

Admission to the intensive care unit (ICU) was necessary in $21.1 \%$ of the patients. Hospitalization time ranged between three and 59 days, with an average of 20 days. Time greater than that was found in two national studies: $9 \%$ in Tavares et al. ${ }^{16}$ and $14 \%$ by Borboletto et al. ${ }^{6}$, which may be justified by the clinical conditions on the patients' admission, as well as complications related to the delay in hospitalization ${ }^{4,16-18}$.

The mortality percentage was $21.1 \%$, which is similar to that described by Oliveira et al., $19 \%{ }^{15}$. In the group of amputees, mortality was $43.1 \%$, above the average of most national studies (38.1\% for major amputation and $5 \%$ for minor $)^{15}$. This illustrates that a significant number of patients evolve with the most serious complications of the diabetic foot, mainly due to the delay in hospital admission ${ }^{19}$. This aspect is related to living outside the metropolitan region, where most services do not have specialized vascular care coverage.

There are several scores to determine the severity of the diabetic ulcers ${ }^{19-20}$. The most used and accepted globally are those of Wagner and PEDIS, which, together with the classification of the University of Texas, try to encompass all the main aspects involved in the foot injury of a diabetic patient, such as the presence of ulcers, ischemia, and infection ${ }^{20-22}$. In the present study, no patient was classified as Wagner's grade 5 and PEDIS grade I. Most were classified as grades 4 (43.9\%) and 3 
(49.1\%), respectively, these data being consistent with those reported in the literature ${ }^{19,20,23,24}$. These findings are useful in stratifying patients with severe foot injuries and need for early intervention due to deep ulceration with osteomyelitis or abscess located in part of the foot.

Thus, the data presented ratify those found in the literature. Furthermore, they reinforce the need for early intervention in our institution, particularly in patients with a male profile, in the sixth decade of life, with low income and education, type 2 diabetes with comorbidities, without adequate management or follow-up, and who already have foot deformities or sensitivity alterations. This analysis suggests that primary care might positively affect the control and prevention of diabetic foot, since it represents the patient's first contact with health professionals, favoring the opportunity to promote awareness about the care and risks related to DM, minimizing the risk of limb loss.

The study has some limitations, such as selection bias, as it analyzed a sample of hospitalized patients who evolved with complications of the diabetic foot, and in a relatively short period of data collection. In addition, we did not assess other clinical variables, such as obesity, glycosylated hemoglobin, and germs found in cultures. In part, this is justified because the data collection depended on the adequate filling of hospital records. Future studies are being conducted at the institution and consider these parameters in the application of the protocol for more reliable and clarifying results. Despite these limitations, this article reported the socioeconomic and demographic profiles of patients hospitalized with complications of the diabetic foot and reinforces the need for early intervention in these patients, whether in outpatient or even in hospital care.

\section{CONCLUSION}

The present study revealed that at the HUJBB, in Belem-Para, the profile of occurrence of diabetic foot was higher in male patients, over 50 years of age. Lowincome patients with little education predominated, with type II diabetes and an infectious foot pattern. The cases were admitted with more advanced Wagner and PEDIS classifications, which correlated with high rates of amputations, impacting mortality.

\title{
R E S U M O
}

\begin{abstract}
Objetivo: traçar o perfil socioeconômico demográfico de pacientes internados com diagnóstico de pé diabético em um hospital terciário de Belém-PA, bem como avaliar os fatores de riscos para amputações de membros inferiores classificando-os de acordo com os critérios de Wagner e PEDIS. Métodos: estudo descritivo, transversal, unicêntrico e analítico realizado mediante questionário estruturado com perguntas objetivas e com posterior análise estatística descritiva de pacientes diagnosticados com pé diabético em um hospital terciário de Belém-PA. Resultados: estudo foi composto por 57 pacientes, com idade variando entre 48 e 84 anos, sendo 66,7\% masculino. A renda medida oscilou entre 01 a 03 salários. O Diabetes Mellitus do tipo II foi predominante (86,0\%). HAS foi a doença associada mais prevalente (62,3\%), seguida da Dislipidemia (52,8\%). Havia 35,1\% fumantes. O tipo mais comum de pé diabético foi o neuropático (59,6\%), seguido pelo infeccioso (50,9\%) e o misto (49,1\%). O tempo de hospitalização variou entre 03 e 59 dias. 43,1\% dos pacientes que foram submetidos a amputações maiores faleceram. Conclusão: a ocorrência de pé diabético foi maior nos pacientes do sexo masculino com mais de 50 anos de idade. Predominaram pacientes de baixa renda e com pouca escolaridade. A maioria dos pacientes foram acometidos por pé diabético do tipo Il e padrão infeccioso e, que necessitaram de intervenção. A maioria dos pacientes foi admitido com classificações mais avançadas de Wagner e PEDIS, o que estava associado à altas taxas de amputações, impactando nos desfechos de mortalidade.
\end{abstract}

Palavras chave: Pé Diabético. Amputação. Extremidade Inferior. Fatores de Risco.

\section{REFERENCES}

1. Soo BP, Rajbhandari S, Egun A, Ranasinghe $U$, Lahart IM, Pappacham JM. Endocrine. Survival at 10 years following lower extremity amputations in patients with diabetic foot disease. Endocrine. 2020;69(1):100-6.

2. Sociedade Brasileira de Diabetes. Diretrizes da
Sociedade Brasileira de Diabetes 2017-2018. São Paulo: Clannad; 2017.

3. Azevedo S, Victor EG, Oliveira DCD. Diabetes mellitus e aterosclerose: noções básicas da fisiopatologia para o clínico geral. Rev Bras Clin Med. 2010;8(6):520-6.

4. Zhang P, Lu J, Jing Y, Tang S, Zhu D, Bi Y. Global epidemiology of diabetic foot ulceration: a 
systematic review and meta-analysis. Ann Med. 2017;49(2):106-16.

5. Monteiro-Soares M, Boyko EJ, Ribeiro I, DinisRibeiro M. Predictive factors for diabetic foot ulceration: a systematic review. Diabetes Metab Res Rev. 2012;28(7):574-600.

6. Bortoletto MSS, Viude DF, Haddad MCL, Karino ME. Caracterização dos portadores de diabetes submetidos à amputação de membros inferiores em Londrina Estado do Paraná. Acta Scientiarum Health Sciences. 2010;32(2):205-13.

7. Pitta GBB, Castro AA, Soares AMMN, Maciel CJ, Silva JDM, Muniz VMT, Asmar SB. Perfil dos pacientes portadores de pé diabético atendidos no hospital escola José Carneiro e na unidade de emergência Armando Lages. J Vasc Bras. 2005;4(1):5-10.

8. Cho NH, Shaw JE, Karuranga S, Huang Y, da Rocha Fernandes JD, Ohlrogge AW, et al. IDF Diabetes Atlas: global estimates of diabetes prevalence for 2017 and projections for 2045. Diabetes Res Clin Pract. 2018;138:271-81.

9. Vileikyte L, Pouwer F, Gonzalez JS. Psychosocial research in the diabetic foot: are we making progress? Diabetes Metab Res Rev. 2020;36 Suppl 1:e3257. Epub 2019 Dec 18.

10. Ministério da Saúde (BR). Secretaria de Estado de Saúde do Distritor Federal. Grupo de trabalho internacional sobre pé diabético. Consenso internacional sobre pé diabético. Brasília (DF), 2001. Disponível em: http://189.28.128.100/Dab/ DocsPublicacoes/Geral/Conce_Inter_Pediabetico. Pdf.

11. Haddad MCL, Bortoletto MSS, Silva RS. Amputação de membros inferiores de portadores de diabetes mellitus: análise dos custos da internação em hospital público. Ciência, Cuidado E Saúde. 2010;9(1):107-13.

12. Nunes MAP, Resende KF, Castro AA, Pitta GBB, Figueiredo LFP Miranda Jr F. Fatores predisponentes para amputação de membro inferior em pacientes diabéticos internados com pés ulcerados no estado de Sergipe. J Vasc Bras. 2006;5(2):123-30.

13. Lazzarini PA, Pacella RE, Armstrong DG, Van Netten JJ. Diabetes-related lower-extremity complications are a leading cause of the global burden of disability.
Diabet Med. 2019;35(9):1297-99.

14. Andrade NHS, Mendes KDS, Faria HTG, Martins TA, Santos MA, Teixeira CRS, Zanetti ML. Pacientes com diabetes mellitus: cuidados e prevenção do pé diabético em atenção primária à saúde. Rev Enferm UERJ;18(4):616-21.

15. Oliveira JC, Taquary SAST, Barbosa AM, Veronezi RJB. Pé diabético e amputações em pessoas internadas em hospital público: estudo transversal. ABCS Health Sci. 2016;41(1):34-9.

16. Everett $E$, Mathioudakis N. Update on management of diabetic foot ulcers. Ann $N$ Y Acad Sci. 2018;1411(1):153-65.

17. Kee KK, Nair HKR, Yuen NP. Risk factor analysis on the healing time and infection rate of diabetic foot ulcers in a referral wound care clinic. J Wound Care. 2019;28(Supl.1):S4-S13.

18. Yazdanpanah $L$, Shahbazian HB, Moravej Aleali A, Jahanshahi A, Ghanbari S, Latifi SM. Prevalence, awareness and risk factors of diabetes in Ahvaz (South West of Iran). Diabetes Metab Syndr. 2016;10(2 Suppl 1):S114-8.

19. Hicks CW, Canner JK, Mathioudakis N, Lippincott $\mathrm{C}$, Sherman RL, Abularrage CJ. Incidence and risk factors associated with ulcer recurrence among patients with diabetic foot ulcers treated in a multidisciplinary setting. J Surg Res. 2020;246:24350.

20. Riaz M, Miyan Z, Zaidi SI, Alvi SF, Fawwad A, Ahmadani MY, et al. Characteristics of a large cohort of patients with diabetes having at-risk feet and outcomes in patients with foot ulceration referred to a tertiary care diabetes unit. Int Wound J. 2016;13(5):594-9.

21. Bravo-Molina A, Linares-Palomino JO, Vera-Arroyo B, Salmerón-Febres LM, Ros-Díe E. Inter-observer agreement of the Wagner, University of Texas and PEDIS classification systems for the diabetic foot syndrome.Foot Ankle Surg. 2018;24(1):60-4. doi: 10.1016/j.fas.2016.10.009.

22. Jeon BJ. Comparison of five systems of classification of diabetic foot ulcers and predictive factors for amputation. Int Wound J. 2017;14(3):537-45.

23. Boyko EJ. How to use clinical signs and symptoms to estimate the probability of limb ischaemia in 
patients with a diabetic foot ulcer. Diabetes Metab Res Rev. 2020;36 Suppl 1:e3241.

24. Khunkaew S, Fernandez R, Sim J. Health-related quality of life among adults living with diabetic foot ulcers: a meta-analysis. Qual Life Res. 2019;28(6):413-27.
Received in: 06/05/2020

Accepted for publication: 28/07/2020

Conflict of interest: no.

Funding source: no.

\section{Mailing address:}

José Maciel Caldas dos Reis

E-mail: macielreis.angiovasc@gmail.com

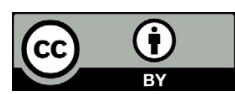

